\title{
EXPLAINING RARITY OF THE NARROWLY ENDEMIC DIPTEROCARPUS CF. CONDORENSIS BY IN SITU PHYSIOLOGICAL MEASUREMENTS
}

\author{
Le Buu Thach ${ }^{(1)}$, Christa Critchley ${ }^{(2)}$ \\ (1) Institute of Tropical Biology, Vietnam. \\ (2) The University of Queensland, Australia \\ (Manuscript Received on October 05 ${ }^{\text {th }} 2011$, Manuscript Revised December $25^{\text {th }}$ 2011)
}

\begin{abstract}
Comparative physiological attributes, obtained by chlorophyll fluorescence and gas exchange techniques, of restricted Dipterocarpus cf. condorensis and widespread Shorea roxburghii species that are actually co-located in Ta Kou Nature Reserve - Binh Thuan Province, provided essential information for understanding rarity of D. condorensis. The narrowly endemic D. condorensis had similar photosynthetic performance to the locally abundant S. roxburghii in more common habitats in which ground water tables are deep (>20m), but had significantly higher photosynthetic activities in its specific habitat, where the ground water level is shallow (<10m). These differences are probably the consequence of evolutionary trade-offs, and represent specializations of the endemic D. condorensis which is only successful in habitat where the ground water is accessible. However, while adaptive in this habitat, these traits may reduce success in other more common habitats in this region.
\end{abstract}

Key words: Chlorophyll fluorescence; Dipterocarpus cf. condorensis; gas exchange; photosynthetic; rarity.

\section{INTRODUCTION}

Most of the dominant trees in forests of Southeast Asia belong to the Dipterocarpaceae family. Besides their role as ecological keystone species, they are major sources of wood and resin in the region. In Vietnam, dry open forests dominated by two dipterocarp species, Dipterocarpus cf. condorensis and Shorea roxburghii G. Don., play an important role in the balance of ecology and landscape along the southern coast. Dipterocarpus cf. condorensis is a newly recognised species, endemic to Vietnam and should be considered as critically endangered because of its limited distribution in fragmented small populations, its sparse regeneration and severe human impacts [1]. By contrast, Shorea roxburghii, despite being assessed as endangered in the IUCN Red List, is a common dipterocarp in South-eastern Vietnam, unusual because it is adapted to withstand adverse climatic conditions and soil types [2]. Shorea roxburghii occurs in dry evergreen or deciduous forests and bamboo forests ranging from lowland to mid-elevation, often on sandy soils in several Asian countries including Cambodia, India, Lao People's Democratic Republic, Malaysia, Myanmar, Thailand and Vietnam. 
A previous study suggested that the cause of rarity in $D$. condorensis may be restriction to a rare habitat [1]. It occurs as a dominant tree in forests that superficially resemble to those of the more common $S$. roxburghii, which dominates forests immediately adjacent to the D. condorensis populations.

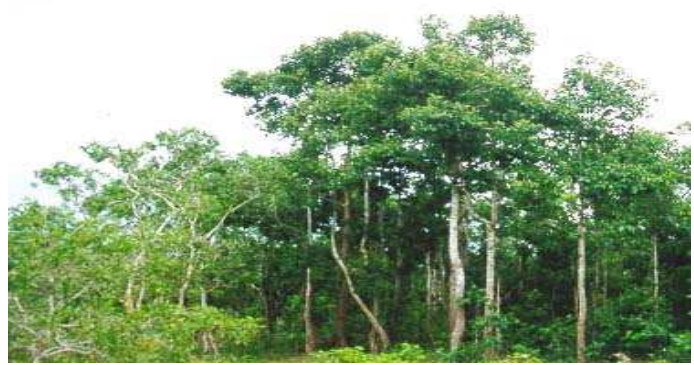

Figure 1. Forests dominated by $D$. condorensis occur at low elevation (2-50 m), adjacent to wetland forest dominated by Melaleuca cajeputi (left), and are burnt frequently.

These two species grow in dry open forests with climatic conditions characteristic of tropical monsoonal climates: average annual temperatures of $26-27^{\circ} \mathrm{C}$, annual rainfall of 1100 to $1500 \mathrm{~mm}$, dry season lasting 5-6 months (i.e. from November to April) in which there are 3-4 months with no rain. For this reason, drought conditions are inherent in this type of forest, and combined with sandy soil, drought becomes very severe at the end of the dry season (February/March). In addition to a restriction in available water, soil drying induces a decrease in nutrient availability, in particular nitrogen with strong interactive effects on plant growth and function [3].

Comparisons of sites dominated by $D$. condorenis with climatically and edaphically similar sites dominated by $S$. roxburghi and using co-occurring species composition as a relative measure of habitat specificity, found that sites dominated by $D$. condorenis were unique. Only two factors distinguished the two forests: ground water tables and forest fires. Forests dominated by $D$. condorensis are located in an area with a shallow ground water table $(<10 \mathrm{~m})$ and are affected more frequently by forest fire than the forest dominated by $S$. roxburghii. In constrast, the forest dominated by $S$. roxburghii are characterized by a deep ground water table (>20m) and are not usually burnt.

It can be therefore assumed that the environmental conditions for the two species in their natural habitats are identical. The deeper ground water level in the forest dominated by S. roxburghii can be considered equivalent to the water stress treatment.

The present case study examined physiological differences between $D$. condorensis and $S$. roxburghii and any association with differences in their dominance. Le 2007 [4] suggested that physiological data, obtained by chlorophyll fluorescence and gas exchange techniques, may provide information for understanding rarity rare plant species.

\section{MATERIAL AND METHODS}

\section{Study area}

The study was carried out in the Ta Kou Nature Reserve, Binh Thuan province (Figure 2). This nature reserve extends from $10^{\circ}$ 
41'28' to $10^{\circ} 53^{\prime} 01$ ', $\mathrm{N}$ latitude and from $107^{\circ}$ 52 ' 14 ' to $108^{\circ} 01^{\prime} 34^{\prime \prime}$ E longitude. Two sites were chosen: a forest dominated by $D$. condorensis near the Headquarters of Ta Kou Nature Reserve management board premises and a forest dominated by $S$. roxburghii located in a central area of the Nature Reserve.

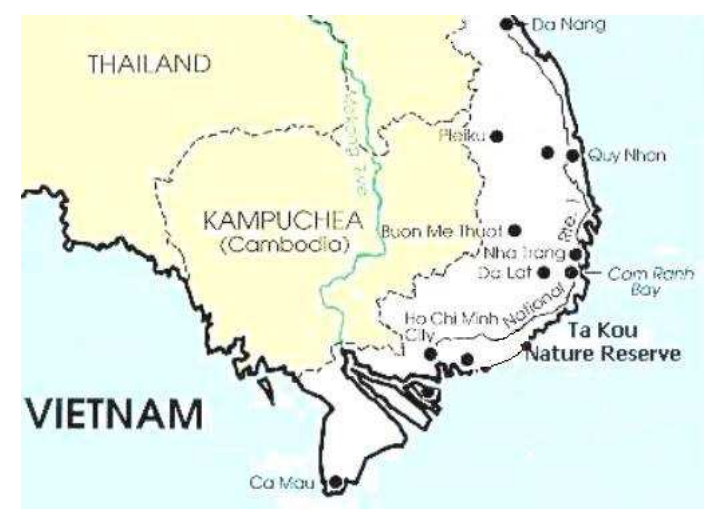

Figure 2. Location of Ta Kou Nature Reserve

\section{Measurements and data analysis}

Measurements were performed in February at the middle of the dry season when drought was becoming extreme.

\section{Chlorophyll fluorescence measurement}

Chlorophyll $a$ fluorescence transients were measured with the Plant Efficiency Analyzer (Handy PEA; Hansatech Ltd., King's Lynn, Northfolk, UK). The fluorescence signal is digitised at different rates depending upon the different phases of the induction kinetic. For the first $300 \mu \mathrm{s}$ fluorescence is sampled at 10 $\mu$ s intervals. This provides excellent time resolution of minimal fluorescence intensity (Fo) and the initial rise kinetics. The time resolution of digitisation is then switched to slower acquisition rates as the kinetics of the fluorescence signal slow. A one second measurement records 120 data points (Handy PEA Manual User's guide).

For chlorophyll fluorescence, 15 fast fluorescence transients were recorded on the upper surfaces of the youngest fully expanded leaves of 5 plants per species (three leaves per plant). During the measurement, the samples were shielded from ambient light by the clips to reach a dark adapted state (adaptation 30 min). Light intensity was $3000 \mu \mathrm{mol}$ photons $\mathrm{m}^{-2} \mathrm{~s}^{-1}$ to generate maximal fluorescence intensity (Fm) for all species. Chlorophyll fluorescence data were analyzed according to the JIP test to calculate the performance index as described in Table 1.

\section{Analysis of the chlorophyll fluorescence transient: the JIP test}

The JIP-test [5] [6] [7] was used to analyse each chl $a$ fluorescence transient. The shape of the OJIP transient has been found to be sensitive to stress such as excess light, temperature, drought, atmospheric $\mathrm{CO}_{2}$ or ozone as well as chemical influences [8] [9] [10] [11] [12] [13].

The following data from the original measurements were used: maximal fluorescence intensity (Fm), minimal fluorescence intensity (Fo), fluorescence intensity at $300 \mu \mathrm{s}(\mathrm{F} 300 \mu \mathrm{s})$ required for calculation of the initial slope (Mo) of the variable $(\mathrm{V})$ component of the transient, and the fluorescence intensity at $2 \mathrm{~ms}$ (the J-step) denoted as $\mathrm{F}_{\mathrm{J}}$.

The JIP-test represents a translation of the original data to biophysical parameters that 
quantify the energy flow through PSII. The initial stage of photosynthetic activity of a reaction center (RC) complex is regulated by three functional steps, namely absorption of light energy (ABS), trapping of excitation energy (TR) and conversion of excitation energy to electron transport (ET). The parameters which all refer to time zero (onset of fluorescence induction) of the flux ratios or yields are the maximum quantum yield of primary photochemistry $\left(\varphi_{\mathrm{Po}}=\mathrm{TRo} / \mathrm{ABS}=\right.$ $\mathrm{Fv} / \mathrm{Fm})$ and the efficiency $(\psi \mathrm{o}=\mathrm{ETo} / \mathrm{TRo})$ with which a trapped exciton can move an electron into the electron transport chain beyond $\mathrm{Q}_{\mathrm{A}}{ }^{-}$.

Recently, the performance index on an absorption basis, PI, was introduced as a multiparametric expression of these three independent steps contributing to photosynthesis. The performance index was calculated as (for a review see Strasser et al. 2000, 2004)

$\mathrm{PI}=\left[\gamma_{\mathrm{RC}} /\left(1-\gamma_{\mathrm{RC}}\right)\right]\left[\left(\varphi_{\mathrm{Po}} /\left(1-\varphi_{\mathrm{Po}}\right)\right][(\psi \mathrm{O} /(1-\psi \mathrm{O})]\right.$

where $\gamma$ is the fraction of reaction centre chlorophyll $\left(\mathrm{Chl}_{\mathrm{RC}}\right)$ per total chlorophyll
$\left(\mathrm{Chl}_{\mathrm{RC}+\text { Antenna }}\right)$. Therefore, $\gamma /(1-\gamma)=\mathrm{Chl}_{\mathrm{RC}} /$ $\mathrm{Chl}_{\text {Antenna }}=\mathrm{RC} / \mathrm{ABS}$. This expression can be de-convoluted into two JIP-test parameters and estimated from the original fluorescence measurements as RC/ABS $=[(\mathrm{F} 2 \mathrm{~ms}-\mathrm{Fo}) /$ $4(\mathrm{~F} 300 \mu \mathrm{s}-\mathrm{Fo})] \cdot(\mathrm{Fv} / \mathrm{Fm})$. The factor 4 is used to express the initial fluorescence rise per $1 \mathrm{~ms}$. The expression RC/ABS represents the active RC density on a chlorophyll basis. The decrease of RC/ABS means an increase in the size of the chlorophyll antenna serving each reaction center. The contribution of the light reactions to primary photochemistry is estimated according to the JIP-test as $\left[\varphi_{\mathrm{Po}} /(1\right.$ $\left.\left.\varphi_{\mathrm{Po}}\right)\right]=\mathrm{Fv} / \mathrm{Fo}$. This component of the PI represents the performance due to the trapping probability $\left(\mathrm{P}_{\mathrm{TR}}\right)$. The contribution of the dark reactions is derived as $[\psi \mathrm{o} /(1-\psi \mathrm{o})]=(\mathrm{Fm}-$ $\mathrm{F} 2 \mathrm{~ms}) /(\mathrm{F} 2 \mathrm{~ms}-\mathrm{Fo})$. It is the performance due to the conversion of excitation energy to electron transport $\left(\mathrm{P}_{\mathrm{ET}}\right)$. The formulae in Table 1 illustrate how each of the above-mentioned biophysical parameters is calculated from the original fluorescence measurements [5] [12].

Table 1. Summary of formulae and definitions of some JIP test parameters

\begin{tabular}{|l|l|l|}
\hline \multicolumn{1}{|c|}{ Parameter } & \multicolumn{1}{|c|}{ Calculation } & \multicolumn{1}{c|}{ Description } \\
\hline \multicolumn{2}{|c|}{ Extracted and technical fluorescence parameters } \\
\hline $\begin{array}{l}\text { Relative variable } \\
\text { fluorescence at } 2 \\
\text { ms: } \mathrm{V}_{\mathrm{J}}\end{array}$ & $=(\mathrm{F} 2 \mathrm{~ms}-\mathrm{Fo}) /(\mathrm{Fm}-\mathrm{Fo})$ & $\begin{array}{l}\text { For unconnected PSII units, equals the } \\
\text { fraction of closed RCs at } 2 \mathrm{~ms} \text { expressed as } \\
\text { a proportion of the total number of RCs } \\
\text { that can be closed. }\end{array}$ \\
\hline $\begin{array}{l}\text { Net rate of PSII } \\
\text { closure: }(\mathrm{dV} / \mathrm{dt}) \mathrm{o}\end{array}$ & $=4(\mathrm{~F} 300 \mu \mathrm{s}-\mathrm{Fo}) /(\mathrm{Fm}-\mathrm{Fo})$ & $\begin{array}{l}\text { An approximation of the slope at the origin } \\
\text { of the fluorescence rise }(\mathrm{dF} / \mathrm{dt}) \mathrm{o} \text { which is a } \\
\text { measure of the rate of the primary }\end{array}$ \\
\hline
\end{tabular}




\begin{tabular}{|c|c|c|}
\hline or Mo & & $\begin{array}{l}\text { photochemistry. It is a net rate because the } \\
\text { reduced } \mathrm{Q}_{\mathrm{A}} \text { can be reoxidised via electron } \\
\text { transport beyond } \mathrm{Q}_{\mathrm{A}} \text {. }\end{array}$ \\
\hline \multicolumn{3}{|c|}{ The flux ratios or yields } \\
\hline $\begin{array}{l}\text { Trapping } \\
\text { probability: } \\
\text { TRo/ABS or } \varphi_{\mathrm{Po}}\end{array}$ & $\begin{array}{l}=(1-\mathrm{Fo}) / \mathrm{Fm} \\
=\mathrm{Fv} / \mathrm{Fm}\end{array}$ & $\begin{array}{l}\text { The probability that an absorbed photon } \\
\text { will be trapped by the PSII RC with the } \\
\text { resultant reduction of } Q_{A} \text {. }\end{array}$ \\
\hline $\begin{array}{l}\text { Electron transport } \\
\text { probability: } \psi \mathrm{o} \text { or } \\
\text { ETo/TRo }\end{array}$ & $=1-\mathrm{Vj}$ & $\begin{array}{l}\text { The probability that an electron residing on } \\
\mathrm{Q}_{\mathrm{A}} \text { will enter the electron transport chain. }\end{array}$ \\
\hline $\begin{array}{l}\text { Performance index } \\
\text { PI }\end{array}$ & $\begin{array}{l}=\left[\gamma_{\mathrm{RC}} /\left(1-\gamma_{\mathrm{RC}}\right)\right]\left[\left(\varphi_{\mathrm{Po}} /(1-\right.\right. \\
\left.\left.\varphi_{\mathrm{Po}}\right)\right][(\psi \mathrm{O} /(1-\psi \mathrm{o})] \\
=(\mathrm{RC} / \mathrm{ABS})\left(\mathrm{P}_{\mathrm{TR}}\right)\left(\mathrm{P}_{\mathrm{ET}}\right)\end{array}$ & $\begin{array}{l}\text { Multi-parametric expression of these three } \\
\text { independent steps contributing to } \\
\text { photosynthesis. }\end{array}$ \\
\hline $\begin{array}{l}\mathrm{RC} / \mathrm{ABS} \\
=\gamma_{\mathrm{RC}} /\left(1-\gamma_{\mathrm{RC}}\right)\end{array}$ & $\begin{array}{l}=\left(\mathrm{Vj} \cdot \varphi_{\mathrm{Po}}\right) / \mathrm{Mo} \\
=[(\mathrm{F} 2 \mathrm{~ms}-\mathrm{Fo}) / 4(\mathrm{~F} 300 \mu \mathrm{s} \\
-\mathrm{Fo})] \cdot(\mathrm{Fv} / \mathrm{Fm})\end{array}$ & $\begin{array}{l}\text { The contribution to the PI of the active RC } \\
\text { density on a chlorophyll basis. }\end{array}$ \\
\hline $\begin{array}{l}\text { Performance due } \\
\text { to } \varphi_{\mathrm{Po}}\left(\mathrm{P}_{\mathrm{TR}}\right)\end{array}$ & $\begin{array}{l}=\left[\varphi_{\mathrm{Po}} /\left(1-\varphi_{\mathrm{Po}}\right)\right] \\
=\mathrm{FV} / \mathrm{Fo}\end{array}$ & $\begin{array}{l}\text { The contribution to the PI of the light } \\
\text { reactions for primary photochemistry }\end{array}$ \\
\hline $\begin{array}{l}\text { Performance due } \\
\text { to } \psi \mathrm{O}\left(\mathrm{P}_{\mathrm{ET}}\right)\end{array}$ & $\begin{array}{l}=[\psi \mathrm{o} /(1-\psi \mathrm{o})] \\
=(\mathrm{Fm}-\mathrm{F} 2 \mathrm{~ms}) /(\mathrm{F} 2 \mathrm{~ms}-\mathrm{Fo})\end{array}$ & $\begin{array}{l}\text { The contribution to the PI of the dark } \\
\text { reactions }\end{array}$ \\
\hline
\end{tabular}

Among several parameters obtained from the chlorophyll fluorescence measurements, the $\mathrm{Fv} / \mathrm{Fm}$ ratio (= TRo/ABS) and the performance index PI were selected for comparison of statistically significantly differences. The reason for this choice was that the $\mathrm{Fv} / \mathrm{Fm}$ ratio is the most widely used photosystem II efficiency indicator. This parameter has been shown to correlate with the number of functional PSII complexes. Many studies have used this ratio as an indicator for stress tolerance or sensitivity [14] [15] [16]. However, some studies have shown this parameter to be quite insensitive to change [17] [18] [10] [5] 13]. Force et al. (2003) [19] demonstrated the advantage of using a number of JIP test derived fluorescence parameters to evaluate PSII function, rather than using only the Fv/Fm ratio. Recently, (for a review see [5] [12]), the PI was introduced and has been used as to quantify the effects of environmental factors such as chilling, heat, drought, chromate, ozone or urban injuries on photosynthesis in several studies [20] [9] [21] [22] [13]. According to the definitions of Strasser et al. (2000, 2004) [5] [12], the PI combines 3 values quantifying the three functional steps of photosynthetic activity by a PSII reaction center complex, from light energy absorption, trapping of excitation energy and 
conversion of this energy to electron transport occurring in PSII. Research by Hermans et al. (2003) [22] showed that PI is more sensitive to environmental change and correlates well with plant vigour and performance. In order to understand in more detail the response in structure and behavior of PSII to the environment, the three components of the PI were compared.

\section{Gas exchange measurements}

Leaf gas exchange was measured, between 08:00 am and 12:30 pm, using a portable photosynthesis system LI-6400 (Li-Cor, Inc., Lincoln, NE, USA) equipped with an artificial light source 6400-02B Red-Blue. Light intensity used is $1500 \mu \mathrm{mol} \mathrm{m} \mathrm{m}^{-2} \mathrm{~s}^{-1}$ which was equal to ambient light intensity in both species. The air $\mathrm{CO}_{2}$ concentration entering the leaf chamber was $400 \mu \mathrm{l} \mathrm{I}^{-1}$ and airflow rate was $500 \mu \mathrm{mol} \mathrm{s}{ }^{-1}$. All gas exchange measurements were performed over $6 \mathrm{~cm}^{2}$ of leaf on attached, intact, youngest fully expanded leaves with 15 replicates (5 plants, 3 leaves per plant) for each species. Five readings were recorded for each leaf after net $\mathrm{CO}_{2}$ assimilation rate had reached steady state and were.

Intercellular $\mathrm{CO}_{2}$ concentration $\left(\mathrm{C}_{\mathrm{i}}, \mu \mathrm{mol}\right.$ $\mathrm{CO}_{2} \mathrm{~mol}^{-1}$ air $)$, transpiration rate $\left(\mathrm{mmol} \mathrm{H}_{2} \mathrm{O}\right.$ $\mathrm{m}^{-2} \mathrm{~s}^{-1}$ ) and stomatal conductance for water vapour ( $g_{s}$ in mol $\mathrm{H}_{2} \mathrm{O} \quad \mathrm{m}^{-2} \mathrm{~s}^{-1}$ ) were simultaneously determined. The equations used to calculate all gas exchange parameters in this study were essentially derived by von Caemmerer and Farquhar (1981). Instantaneous water use efficiency (WUE) was calculated as described by Leffler et al. (2004)

[23]: WUE $\left(\mathrm{mmol} \mathrm{mol}^{-1} \mathrm{~s}^{-1}\right)=\mathrm{CO}_{2}$ assimilation rate $\left(\mu \mathrm{mol} \mathrm{m} \mathrm{m}^{-2} \mathrm{~s}^{-1}\right) /$ transpiration rate $\left(\mathrm{mmol} \mathrm{m}^{-2} \mathrm{~s}^{-1}\right)$.

Statistical analyses were performed using SPSS 10.0 software (SPSS Inc.: Chicago, USA). One-way ANOVA (Bonferoni post-hoc test) at $P<0.05$ was used to test whether there were significant differences between mean values.

\section{RESULTS AND DISCUSSION}

The performance index (PI) of the two dipterocarp species were similar in the forest dominated by $S$. roxburghii, while significant differences in PI $(P<0.05)$ between $D$. condorensis and $S$. roxburghii were found in the forest dominated by D. condorensis (Figure 3). These results indicate that the two species exhibited similar photosynthetic performance in sites where the ground water level is deep. In contrast, the higher PI of D. condorensis in the forest dominated by $D$. condorensis, was consistent with its dominance in this forest, where the ground water level is shallower.

Two previous studies [1] [24] reported that D. condorensis may be better able to reach the ground water because it has a deep root system to $10 \mathrm{~m}$ depth [1] and maintains higher leaf water potentials than other canopy species in the dry open forest dominated by dipterocarp species [24]. By maintaining higher water uptake in the dry season, D. condorensis can maintain a higher number of active reaction centers, indicated by higher RC/ABS (Table 2, 
$P<0.05)$ and thus maintain higher photosynthetic rates than $S$. roxburghii.

Table 2. Chlorophyll fluorescence and gas exchange parameters of D. condorensis and S. roxburghii in the forest dominated by $S$. roxburghii and forest dominated by D. condorensis. Values are averages of

15 replicates $( \pm \mathrm{SEM})$. Different superscript letters indicate significant differences between the two species in each type of forest (ANOVA, Bonferoni post-hoc test, $P<0.05$ ).

\begin{tabular}{|c|c|c|c|c|}
\hline \multirow[t]{2}{*}{ Species } & \multicolumn{2}{|c|}{$\begin{array}{c}\text { Forest dominated by } \\
\text { S. roxburghii }\end{array}$} & \multicolumn{2}{|c|}{$\begin{array}{c}\text { Forest dominated by } \\
\text { D. condorensis }\end{array}$} \\
\hline & D. condorensis & S. roxburghii & D. condorensis & S. roxburghii \\
\hline \multicolumn{5}{|c|}{ Chlorophyll fluorescence parameters } \\
\hline $\mathrm{Fv} / \mathrm{Fm}$ & $0.80(0.005)$ & $0.79(0.01)$ & $0.81(0.003)$ & $0.80(0.005)$ \\
\hline $\mathrm{RC} / \mathrm{ABS}$ & $0.56(0.01)$ & $0.58(0.01)$ & $0.66(0.01)^{\mathrm{a}}$ & $0.59(0.01)^{\mathrm{b}}$ \\
\hline $\mathrm{P}_{\mathrm{TR}}$ & $4.05(0.12)$ & $3.81(0.12)$ & $4.37(0.10)$ & $3.94(0.11)$ \\
\hline $\mathrm{P}_{\mathrm{ET}}$ & $0.91(0.07)$ & $1.09(0.07)$ & $1.19(0.05)$ & $1.10(0.05)$ \\
\hline PI & $2.20(0.16)$ & $2.50(0.13)$ & $3.46(0.14)^{\mathrm{a}}$ & $2.70(0.13)^{b}$ \\
\hline \multicolumn{5}{|c|}{ Gas exchange parameters } \\
\hline $\mathrm{A}_{\max }$ & $1.10(0.23)$ & $0.69(0.21)$ & $4.70(0.42)^{\mathrm{a}}$ & $1.52(0.06)^{b}$ \\
\hline $\mathrm{g}_{\mathrm{s}}$ & $0.14(0.01)$ & $0.016(0.001)$ & $0.08(0.01)^{\mathrm{a}}$ & $0.037(0.004)^{b}$ \\
\hline $\mathrm{C}_{\mathrm{i}}$ & $357(2.27)$ & $309(14.56)$ & $263(1.43)$ & 261(11.72) \\
\hline WUE & $0.11(1.42)^{b}$ & $2.92(0.99)^{\mathrm{a}}$ & $0.60(0.01)^{b}$ & $1.04(0.11)^{\mathrm{a}}$ \\
\hline
\end{tabular}

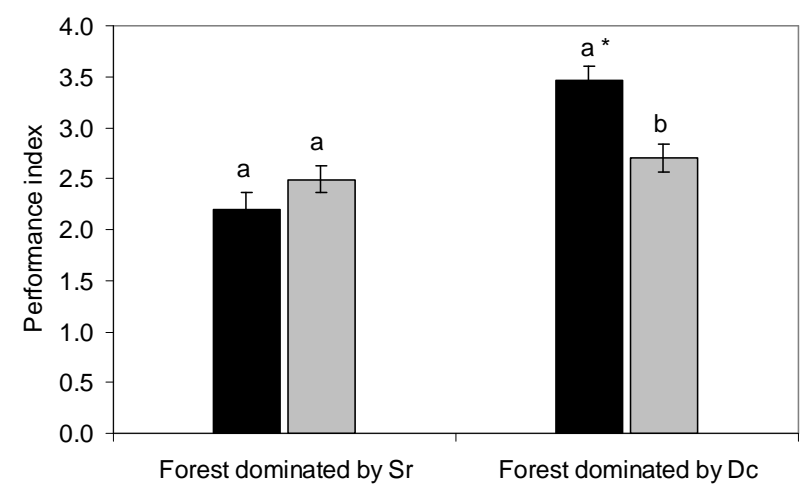

Figure 3. The performance index PI of D. condorensis (Dc, black bars) and S. roxburghii (Sr, grey bars) in the forest dominated by S. roxburghii (left) and forest dominated by D. condorensis (right). Values are averages of 15 replicates $( \pm$ SEM). Different letters indicate significant differences between the two species in each type of forest. The asterisk indicates significant difference between the two forest types (ANOVA, Bonferoni post-hoc test, $P<0.05)$. 
Gas exchange data measured in $D$. condorensis and S. roxburghii in the two forest types were consistent with chlorophyll fluorescence data, showing similar values between the two species in the forest dominated by $S$. roxburghii, but not in $D$. condorensis dominated forest (Figure 4 and Table 2). The lower PI (as well as their three components), coupled with lower $\mathrm{A}_{\max }$ of the two dipterocarp species in forest dominated by $S$. roxburghii, compared to values in $D$. condorensis dominated forest indicated that plants were suffering more severe drought in the site with deeper ground water level. Under extreme drought conditions, the plants' fitness in the field depends on its ability to efficiently use and take up water. Water use efficiency of $S$. roxburghii, measured in $S$. roxburghii dominated forest, was 26-fold higher than that of D. condorensis ( $P<0.001$, Table 2). This difference was much less in the forest dominated by $D$. condorensis, i.e. only 1.7 -fold $(P<0.05)$.

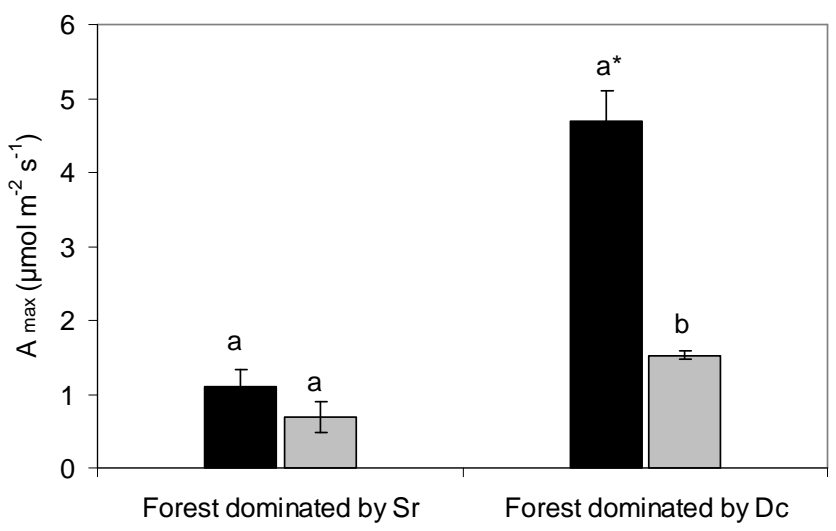

Figure 4. Maximum $\mathrm{CO} 2$ assimilation rates of $\mathrm{D}$. condorensis (Dc, black bars) and S. roxburghii (Sr, grey bars) in the forest dominated by S. roxburghii (left) and forest dominated by D. condorensis (right). Values are averages of 15 replicates $( \pm$ SEM). Different letters indicate significant differences between the two species in each type of forest. The asterisk symbol indicates significant differences for each species between the two forest types (ANOVA, Bonferoni post-hoc test, $P<0.05$ ).

S. roxburghii exhibited adaptive capacity to low water availability by using less water, increasing water use efficiency and thus being more tolerant and resistant to water deficits. It, therefore, dominates the forest where the ground water level is deep, partly because of high elevation, or inaccessible with only a thin layer of rocky soil.
The narrowly endemic D. condorensis appeared to be adapted to habitat with a shallower ground water table, by increasing root length to take up water better than $S$. roxburghii. Thus, D. condorensis can maintain considerable carbon fixation during the dry season which leads to higher growth rates and dominance in the forest where the ground water table is shallow $(<10 \mathrm{~m})$. However, investing 
heavily into root growth most likely contributes to this species' success in this habitat but may make it less competitive in habitats where ground water becomes inaccessible. This explanation is consistent with the hypothesis that edaphic endemics are genetically fixed specialists, with physiological and morphological adaptations necessary for survival in their specific environments. In other habitats these relatively fixed traits may be maladaptive and incur a fitness cost [25] [26].

\section{CONCLUSION}

The narrowly endemic $D$. condorensis had similar photosynthetic performance to the locally abundant $S$. roxburghii in more common habitats of coastal sandy soil region in which ground water tables are deep (>20m), but had significantly higher photosynthetic activities in its specific habitat, where the ground water level is shallow $(<10 \mathrm{~m})$. These differences between the endemic $D$. condorensis and locally abundant $S$. roxburghii are probably the consequence of evolutionary trade-offs, and represent specializations of the endemic D. condorensis which is only successful in habitat where the ground water is accessible. However, while adaptive in this habitat, these traits may reduce success in other more common habitats in this region. $S$. roxburghii probably have higher photosynthetic performance in wet season when water availability is high. Thus, physiological attributes and water potential should be tested in wet season to find out this possibility. With regard to conservation, because the endemic $D$. condorensisis restricted by its water demand, the sites for reforestation programs of this species should be considered where these meet its water requirements.

Findings in this field study confirmed the usefulness of the comparative approach based on physiological profiles to explain plant rarity. The Performance Index (PI), obtained from Chlorophyll fluorescence measurement, emerged as a more sensitive indicator for environmental stress than Fv/Fm. The Performance Index and its three components are useful quantitative and non-destructive indicators of plant stress which can be used in situ to assess plant populations. In addition, using gas exchange technique will provide the photosynthetic carbon gain at the leaf level and confirm the results of Chlorophyll fluorescence technique. 


\title{
GIẢI THÍCH TÍNH PHÂN BỐ HẸP QUA KHẢO SÁT ĐẶC ĐIỂM SINH LÝ CỦA DÂU CÁT -DIPTEROCARPUS CF. CONDORENSIS
}

\author{
Lê Bửu Thạch ${ }^{(1)}$ Christa Critchley ${ }^{(2)}$ \\ (1) Viện Sinh học Nhiệt đới \\ (2) Đại học Queensland, Úc
}

TÓM TÁT: Các kỹ thuật huỳnh quang diệp lục và trao đổi khí đã đuợc sử dụng để so sánh các đặc điểm quang hơp của loài Dầu Cát-Dipterocarpus. cf. condorensis (đặc hũu hẹp) và loài SếnShorea roxburghii (thông thuờng) tại Khu BTTN Tà Kóu - Tỉnh Bình Thuận. Kết quả khảo sát đã góp phần giải thích nguyên nhân phân bố hẹp của Dầu Cát. Dầu Cát có hiệu suất quang hợp tuơng tư nhu Sến ở các khu vưc cả hai loài cùng mọc nơi có mưc nuơóc ngầm sâu (> 20m), nhung có hoạt động quang hợp cao hơn ở nơi mục nuớc ngầm cạn $(<10 m)$. Quá trình tiến hóa đã hình thành các đặc tính chuyên biệt của Dầu Cát, giúp cho loài này phát triển mạnh ở nhũng noi có mưc nước ngầm cạn. Tuy nhiên, nhũng thuộc tính này có thể là nguyên nhân làm giảm sức cạnh tranh của Dầu Cát ở các môi truờng sống khác phổ biến hơn trong khu vưc.

Tù khóa: Huỳnh quang diệp lục, Dipterocarpus cf. condorensis, trao đổi khí, quang hợp.

\section{REFERENCES}

[1]. Le BT, Study on ecological characteristics of Dipterocarpus $c f$. condorensis in South-eastern Vietnam Master thesis, University of Science, VNU-HCM, Vietnam (2000).

[2]. Ashton P Shorea, roxburghii. In: IUCN 2006. 2006 IUCN Red List of Threatened Species. <www.iucnredlist. org>. Downloaded on 12 February 2007 (1998).

[3]. Chaves MM, Maroco JP and Pereira JS Review: Understanding plant responses to drought - from genes to the whole plant, Functional Plant Biology, 30, 239-264 (2003).
[4]. Le BT, Alison S, Susanne S, Christa C, The OJIP fast fluorescence rise characterizes Graptophyllum species and their stress responses, Photosynth Res., 94, 423-436 (2007).

[5]. Strasser RJ, Srivastava A and TsimilliMichael M,.. In: Yunus M, Pathre U, and Mohanty $\mathrm{P}$ (eds) Probing Photosynthesis:Mechanisms, Regulation and Adaptation. Chapter 25: 445-483. Taylor and Francis, London (2000).

[6]. Strasser RJ and Strasser BJ, Measuring fast fluorescence transients to address environmental questions: The JIP-test, In: Mathis P (ed) Photosynthesis: from Light to Biosphere. Kluwer Academic Publishers, Dordrecht, Netherlands (1995). 
[7]. Strasser RJ and Tsimilli-Michael M, Structure function relationship in the photosynthetic apparatus: a biophysical approach. In: Pardha SP (ed) Biophysical Processes in Living Systems, Chapter 16, pp 271 - 303. Science Publishers, Inc. Enfield (NH), USA (2001).

[8]. Appenroth KJ, Stockel J, Srivastava A and Strasser RJ, Multiple effects of chromate on the photosynthetic apparatus of Sprirodela polyrhiza as probed by OJIP chlorophyll a fluorescence measurements, Environmental pollution, 115, 49-64 (2001).

[9]. Clark AJ, Landolt W, Bucher JB and Strasser RJ, Beech (Fagus sylvatica) response to ozone exposure assessed with a chlorophyll a fluorescence performance index, Environmental Pollution, 109, 501-507 (2000).

[10]. Krüger GHJ, Tsimilli-Michael $\mathrm{M}$ and Strasser RJ, Light stress provokes plastic and elastic modifications in structure and function of photosystem II in camellia leaves, Physiologia plantarum, 101, 265-277 (1997).

[11]. Moise N and Moya I, Correlation between lifetime heterogeneity and kinetics heterogeneity during chlorophyll fluorescence induction in leaves: 1. Mono-frequency phase and modulation analysis reveals a conformational change of a PSII pigment complex during the IP thermal phase, Biochimica et Biophysica Acta ,1657, 33-46 (2004).

[12]. Strasser RJ, Srivastava A and TsimilliMichael M, Analysis of the fluorescence transient, In: Papageogiou G and Govindjee (eds) Chlorophyll a Fluorescence: A signature of Photosynthesis, pp. 321-362. Springer, Dordrecht, Netherlands (2004).

[13]. Strauss AJ, Kruger GHJ, Strasser RJ and Van Heerden PDR, Ranking of dark chilling tolerance in soybean genotypes probed by the chlorophyll a fluorescence transient O-J-I-P. Environmental and Experimental Botany, 56, 147-157 (2006).

[14]. Cavender-Bares J and Bazzaz FA, From leaves to ecosystems: Using Chlorophyll fluorescence to access photosynthesis and plant function in ecological studies, In: Papageogiou GC and Govindjee (eds). Chlorophyll a Fluorescence: A signature of Photosynthesis, pp. 737755. Spinger, Dordrecht, Netherlands (2004).

[15]. Critchley C, Photoinhibition, In: Raghavendra AS (eds) Photosynthesis. Cambridge University Press, Cambridge (1998).

[16]. Ogaya R and Penuelas J, Comparative seasonal gas exchange and chlorophyll fluorescence of two dominant woody species in a Holm Oak Forest, Flora, 198, 132-141 (2003). 
[17]. Filella I, Llusia J, Pinol J and Penuelas $\mathrm{J}$, Leaf gas exchange and fluorescence of Phillyrea latifolia, Pistacia lentiscus and Quercus ilex saplings in severe drought and high temperature conditions, Environmental and Experimental Botany, 39, 213-220 (1998).

[18]. Force L, Applications of the JIP-test of chlorophyll fluorescence - PhD Thesis, The University of Queensland, Brisbane (2002).

[19]. Force L, Critchley C and Van Rensen JJS, New fluorescence parameters for monitoring photosynthesis in plants. 1. The effect of illumination on the fluorescence parameters of the JIP-test, Photosynthesis Research, 78, 17-33 (2003).

[20]. Appenroth KJ, Stockel J, Srivastava A and Strasser RJ, Multiple effects of chromate on the photosynthetic apparatus of Sprirodela polyrhiza as probed by OJIP chlorophyll a fluorescence measurements, Environmental pollution, 115, 49-64 (2001).

[21]. De Ronde JA, Cress WA, Krüger GHJ, Strasser RJ and Van Staden J, Photosynthetic response of transgenic soybean plants, containing an Arabidopsis P5CR gene, during heat and drought stress, Journal of Plant Physiology, 161, 1211-1224 (2004).

[22]. Hermans C, Smeyers M, Rodriguez RM, Eyletters M, Strasser R and Dehaye JP, Quality assessment of urban's trees: A comparative study of physiological characterisation, airborne imaging and on site fluorescence monitoring by the OJIP test, Journal of Plant Physiology ,160, 81-90 (2003).

[23]. Leffler AJ, Ivans C Y, Ryel RJ and Caldwell MM, Gas exchange and growth responses of the desert shrubs Artemisia tridentata and Chrysothamnus nauseosus to shallow-vs. deepsoil water in a glasshouse experiment, Environmental and Experimental Botany, 51, 9-19 (2004).

[24]. Mitlöhner R, Truong QT and Weidelt HJ, Waldtypenbildung und Wasserverfügbarkeit im Monsunwald des südöstlichen, Vietnam (Forest type development and water availability in monsoon forests of Southeastern Vietnam), Forstarchiv, 68, 244-250 (1997).

[25]. Kruckeberg AR and Rabinowitz D, Biological aspects of endemism in higher plants, Annual Review of Ecology and Systematics, 16, 447-479 (1985).

[26]. Poot $\mathrm{P}$ and Lambers H, Are trade-offs in allocation pattern and root morphology related to species abundance? A congeneric comparison between rare and common species in the southwestern Australian flora, Journal of Ecology, 91, 58-67 (2003). 